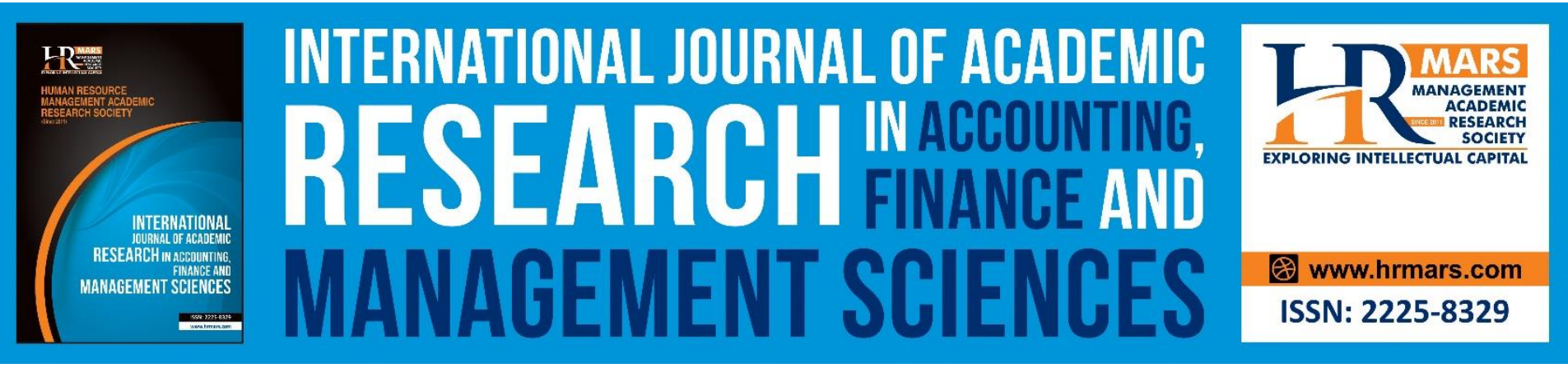

\title{
Bibliometric Overview and Retrospective Analysis of Asset Management Research between 1965 and 2020
}

\author{
Ahmad Tajudin, I. K. Norziaton, Aida Hazlin Ismail
}

To Link this Article: http://dx.doi.org/10.6007/IJARAFMS/v11-i3/11371 DOI:10.6007/IJARAFMS /v11-i3/11371

Received: 10 July 2021, Revised: 18 August 2021, Accepted: 29 August 2021

Published Online: 21 September 2021

In-Text Citation: (Tajudin et al., 2021)

To Cite this Article: Tajudin, A., Norziaton, I. K., \& Ismail, A. H. (2021). Bibliometric Overview and Retrospective Analysis of Asset Management Research between 1965 and 2020. International Journal of Academic Research in Accounting Finance and Management Sciences, 11(3), 772-800.

Copyright: (c) 2021 The Author(s)

Published by Human Resource Management Academic Research Society (www.hrmars.com)

This article is published under the Creative Commons Attribution (CC BY 4.0) license. Anyone may reproduce, distribute, translate and create derivative works of this article (for both commercial and non-commercial purposes), subject to full attribution to the original publication and authors. The full terms of this license may be seen

at: http://creativecommons.org/licences/by/4.0/legalcode

Vol. 11, No. 3, 2021, Pg. 772 - 800

http://hrmars.com/index.php/pages/detail/IJARAFMS

JOURNAL HOMEPAGE

Full Terms \& Conditions of access and use can be found at

http://hrmars.com/index.php/pages/detail/publication-ethics 


\title{
Bibliometric Overview and Retrospective Analysis of Asset Management Research between 1965 and 2020
}

\author{
Ahmad Tajudin \\ Accountant General Department, Putrajaya \\ I. K. Norziaton, Aida Hazlin Ismail \\ Faculty of Accountancy, Universiti Teknologi Mara Shah Alam
}

\begin{abstract}
Asset management is a "joined in" organisational activity used to realise value from its controlled resources. Asset management evolved from simple maintenance, which was treated as a "necessary evil" in the 1970s, to the current position, i.e., among the core functions of organisational strategies and closely dependent technology. Studying of the asset management evolution is vital in providing valuable insights into the inclusiveness and global scope of asset management research. Thus, this study aimed to investigate the evolution and dissemination of asset management research; determine the main areas that are being debated in research on asset management; and identify the prominent authors in research into asset management and their collaborations. A bibliometric analysis was conducted comprised of 4,190 published items of literature pertaining to asset management indexed in the Scopus database in January 2021. Findings showed that asset management attracted Western scholars' attention in its early growth period, beginning from 1965. The number of publications increased steadily until the 1990s, a rise that accelerated during the 2000s. Asset management research has become well-developed, but inclusiveness has yet to be properly promoted. A positive cross-country collaboration has been achieved; however, there is a gap in asset management research in certain countries compared to the rest of the world. Future studies should explore and bridge any potential gaps in asset management development, and focus on varied asset management strategies across various countries.
\end{abstract}

Keywords: Asset Management, Facility Management, Maintenance Management, Bibliometric Analysis

\section{Introduction}

Asset management is a strategic and integrated process involving various disciplines such as engineering, operations, management and maintenance, the aim of which is to gain the greatest lifetime benefits and returns on assets (Amadi-Echendu et al., 2010; Laue et al., 2014; Mirhosseini \& Keynia, 2021). Asset management needs the participation of different areas, primarily human 
INTERNATIONAL JOURNAL OF ACADEMIC RESEARCH IN ACCOUNTING, FINANCE AND MANAGEMENT SCIENCES

Vol. 11, No. 3, 2021, E-ISSN: 2225-8329 @ 2021 HRMARS

activities, to manage individuals who control assets and incorporate asset-related policies in the operational and organisational frameworks, particularly asset maintenance (Nel \& Jooste, 2016). The importance of asset management has been discussed, developed, and taken into account for several decades.

The research on asset management is rapidly developing and has inspired various approaches, framework developments, analyses and discussions. Asset management and facilities management have many similarities, especially as the function of both incorporates technical maintenance management (Mason, 2017). The functions of asset management and facilities management also include strategic planning, risk management, financial planning and control, and quality management.

Previously, studies have explored the trend of asset management research. Analysis conducted has concentrated on investigating the timeframe, and analysing different research objectives, perspectives and contributions. A study by Leiblein et al (2016) appeared as the first bibliographic review of asset management literature. The study analysed facility management, specifically in hospitals. They analysed keywords and ranked the publications based on journals. Meanwhile, Garramone et al (2020); Li et al (2019) examined asset management from different perspectives, but have yet to define whether progress is similarly shared or collaborated on worldwide. This question is important, as asset management is not a new discipline; the first reference to holistic asset management was recorded in the 1970s under the term 'terotechnology' (Konstantakos et al., 2019). Asset management also allows organisations to create, enhance and or sustain a resource with corporate governance values, ensuring the asset management paradigm shift is much broader than the scope of maintenance (Amadi-Echendu, 2004). In a competitive landscape, it is important to manage assets effectively and efficiently to achieve optimal returns and gain competitive advantages. This cannot be done by only considering the asset's entire lifetime with all the associated costs and maintenance, but instead, asset management should also be viewed from a different perspective (Campbell \& Reyes, 2014).

This paper seeks to examine the scientific literature on asset management by conducting a bibliometric analysis and investigating three main research questions. These include studying how asset management research has evolved and is distributed, what major areas of asset management research are discussed, as well as who the prominent individuals in asset management research are, and their collaborations with other authors from different countries.

The above questions will be answered via several objectives

a) To investigate the evolution and dissemination of asset management research;

b) To determine the main areas under debate in research on asset management; and

c) To identify the prominent authors of research on asset management and their collaborations

Therefore, it is vital to conduct this research to better understand the asset management phenomenon with regards to its global reach and collaborations. The latest data needs to be examined to aid the formulation of recommendations for future research in the development of the asset management topic. 
INTERNATIONAL JOURNAL OF ACADEMIC RESEARCH IN ACCOUNTING, FINANCE AND

MANAGEMENT SCIENCES

Vol. 11, No. 3, 2021, E-ISSN: 2225-8329 @ 2021 HRMARS

The remainder of this paper will discuss the literature review, which is followed by a description of the research methods and results. The following sections contain a discussion of different considerations and issues to acknowledge when answering the research questions listed above.

\section{Literature Review}

This section outlines the literature on asset management, including the evolution and the gaps within bibliometric reviews of asset management research.

\section{Asset Management}

Asset management is a "joined in" activity of an organisation used to realise value from its controlled resources. According to Publicly Available Specification 55 (PAS 55), asset management can be defined as "... systematic and coordinated activities and practices through which an organisation optimally and sustainably manages its assets and asset systems, their associated performance, risks and expenditures over their life cycles for the purpose of achieving its organisational strategic plan". The United States Department of Transport described asset management as a comprehensive process for cost-effective asset maintenance, upgrading and operations. Asset management can be regarded as a combination of engineering fundamentals, organisational processes and economic theory. Therefore, within the organisational structure, asset management needs the participation of different areas, primarily human activities, to manage individuals who control assets and incorporate asset-related policies into operational and organisational frameworks, particularly asset maintenance (Nel \& Jooste, 2016).

Managing assets allows an organisation to create, enhance, and sustain its business as it can increasing the economic productivity (Sara et al., 2021) and allow the organisation to save money for long term (Mastroianni et al., 2021). The critical process in managing assets is to maintain them so that their function remains. A study by Schraven et al (2011) indicates that a key challenge to achieving effective asset management is the establishment of an alignment between asset objectives, situation and intervention, the formulation of asset objectives, and the management of multiple actors with different interests.

The focus of asset management is the efficient management of an asset's life cycle, from acquisition to use, maintenance, and disposal. The emphasis is not on the revenue it might create for an organisation, but the results, risks and costs involved in reaching the best solutions (Hastings, 2015; Schuman \& Brent, 2005).

Generally, asset management activity begins with planning to acquire assets and ends when the asset is disposed of; the asset's whole life should be monitored. This activity is known as the life cycle, which manages all assets in their lifespan, and includes creating, establishing, exploiting and, finally, divesting of an asset (Amadi-Echendu, 2004).

\section{Evolution of Asset Management}

Asset Management is a term that has been used in organisations and presents different meanings, depending on where it is used (Alfatih et al., 2015). As in other disciplines, an organisation faces challenges in managing its assets. Asset management sometimes conflicts with the intention to acquire assets; to generate future economic benefits or for the services potentially directly attributable to flow to the organisation, assets have to respond to the economy, politics, and society (MPSAS17). This indicates that managing an asset involves multiple parties, not just "doing things" 
INTERNATIONAL JOURNAL OF ACADEMIC RESEARCH IN ACCOUNTING, FINANCE AND MANAGEMENT SCIENCES

Vol. 11, No. 3, 2021, E-ISSN: 2225-8329 @ 2021 HRMARS

with assets. Asset management must be a collaborative process of understanding and using assets as valuable sources of value and service delivery mechanisms (IAM, 2015).

Asset management is not a recent discipline, but it has been reinforced, and it is continuously evolving (Amadi-Echendu et al., 2010; Wijnia, 2016). According to Konstantakos et al. (2019), the first use of the term holistic asset management was recorded in the 1970s under the name of terotechnology. Terotechnology is a combination of the accessibility of the system approach and numerate techniques, applied together to enable the manufacturing engineer to consider situations a step further by overcoming various user issues. It should also be concerned with identifying the degree of reliability of the issue (Harvey, 1977). This discipline was based on sound fundamentals, conventional reliability and sustainability practices to encourage industrial profitability.

Later, in the 1980s, technology was created, particularly in information systems, and resulted in the asset management discipline scope being strengthened with the introduction of software systems and predictive maintenance techniques. This technology allowed organisations to adopt the systematised orientation of asset management and simulate the core function activities they conducted.

Further, asset management emerged under the modern paradigm of "Enterprise Asset Management" in the 1990s. The major drivers of this phase were to minimise the corrective time frame by conducting root-cause failure analysis, introducing mature and effective software systems, and implementing risk-based safety strategies.

Holistically, a higher level of asset management maturity and convergence emerged in 2000. Organisations strived to manage assets to gain the greatest possible lifetime effectiveness, utilisation, and returns by collaborating with third parties, such as vendors and clients, to create a holistic, strategic process that integrated finance, management, engineering, operations and maintenance processes (Pais et al., 2020). The asset management process should be used in complete life cycles of assets - design, acquisition, operation, maintenance, and disposal and in risk-based management of assets and related human resources to achieve even greater value. The holistic approach helps organisations to leverage benefits beyond the maintenance phase of the asset's life cycle.

To date, the evolution of asset management has focused on being technologically driven (Blache, 2019). Managing assets is aligned with technological change, and the approach is moving to precision maintenance, cloud-based data storage and analysis, the Internet of Things (IoT), artificial intelligence, and edge computing. Edge computing is computing that is performed close to the data source. The lower costs of sensors and processing are the most critical computing capabilities. It uses analytics for maintenance forecasts and to set out required steps, such as contacting a mobile asset for faster repair. Meanwhile, artificial intelligence enables users to gather, store, and apply information in new environments. The use of technology can help organisations achieve advantages over competitors.

It can be concluded that asset management evolved from simple maintenance, which was treated as a "necessary evil" in the 1970s, to the current position. In the new evolution, asset management activities are treated as core functions of organisational strategies and closely depend on technology. This has changed the approach and landscape, and allowed organisations to benefit. 
INTERNATIONAL JOURNAL OF ACADEMIC RESEARCH IN ACCOUNTING, FINANCE AND MANAGEMENT SCIENCES

Vol. 11, No. 3, 2021, E-ISSN: 2225-8329 @ 2021 HRMARS

\section{Gaps in the Bibliometric Analysis of Asset Management Research}

Bibliographic research generally consists of reports containing analyses from various perspectives. Several bibliometric studies related to asset management research have been conducted in the past, as shown in Table 1. These studies demonstrated a significant, accumulative increase in asset management research across the period until 2020. However, none of these studies has comprehensively covered publications related to asset management research from the beginning of the period.

Table 1. Previous documents on bibliometric analysis of asset management research

\begin{tabular}{|c|c|c|c|c|}
\hline Author & $\begin{array}{l}\text { Data } \\
\text { source }\end{array}$ & Keyword & Year & Bibliometric indicator \\
\hline $\begin{array}{l}\text { Garramon } \\
\text { e et al. } \\
(2020)\end{array}$ & $\begin{array}{l}\text { Scopus } \\
\text { and } \\
\text { Wos }\end{array}$ & $\begin{array}{l}\text { ((geographic information } \\
\text { system* OR gis) OR } \\
\text { (building information } \\
\text { modelling OR building } \\
\text { information modelling OR } \\
\text { bim)) AND (asset* } \\
\text { management OR am) AND } \\
\text { (infrastructure) in the } \\
\text { Scopus ("Article title, } \\
\text { Abstract, Keywords" field) } \\
\text { and in WoS ("Topic" field). }\end{array}$ & $\begin{array}{l}2013 \\
\text { to } \\
2020\end{array}$ & $\begin{array}{l}\text { i. Published scientific } \\
\text { literature } \\
\text { ii. Keyword co-occurrence } \\
\text { network } \\
\text { iii. Collaboration Network, } \\
\text { by Country } \\
\text { iv. Selected articles } \\
\text { concerning different } \\
\text { information } \\
\text { management } \\
\text { approaches } \\
\text { v. Classification by asset } \\
\text { management Function }\end{array}$ \\
\hline $\begin{array}{l}\text { Li et al. } \\
\text { (2019) }\end{array}$ & $\begin{array}{l}\text { Web of } \\
\text { Science } \\
\text { (WoS) }\end{array}$ & $\begin{array}{l}\text { ("facilit* management") in } \\
\text { the } \\
\text { Title/Abstract/Keywords }\end{array}$ & $\begin{array}{l}1995 \\
\text { to } \\
2018\end{array}$ & $\begin{array}{l}\text { i. Number of FM } \\
\text { publications per year } \\
\text { ii. op-10 journals with } \\
\text { impact factor and } \\
\text { CiteScore } \\
\text { iii. Top-10 publications with } \\
\text { the most citations } \\
\text { iv. The keyword co- } \\
\text { occurrence analysis } \\
\text { v. The keyword cluster } \\
\text { analysis }\end{array}$ \\
\hline $\begin{array}{l}\text { Leiblein et } \\
\text { al. (2016) }\end{array}$ & $\begin{array}{l}\text { Scopus, } \\
\text { Europe } \\
\text { PMC, } \\
\text { Elsevier, } \\
\text { and } \\
\text { Emerald } \\
\text {. }\end{array}$ & $\begin{array}{l}\text { ("Legionella" OR } \\
\text { "Legionnaires Disease" OR } \\
\text { "Healthcare" OR "health } \\
\text { care" OR “Hospital” } \\
\text { OR "Environment" OR } \\
\text { "Facilities" OR "facility" } \\
\text { OR "Water" OR "water } \\
\text { system" OR "water }\end{array}$ & $\begin{array}{l}\text { No } \\
\text { time } \\
\text { limit }\end{array}$ & $\begin{array}{l}\text { i. Rank list of the top } 20 \\
\text { most relevant articles by } \\
\text { the presence of the } \\
\text { three principal } \\
\text { keywords. } \\
\text { ii. Rank list of the top } 20 \\
\text { most relevant articles by }\end{array}$ \\
\hline
\end{tabular}




\begin{tabular}{ll}
\hline distribution system" OR & $\begin{array}{l}\text { the total counts of the } \\
\text { "Wrincipal keywords }\end{array}$ \\
"Nosocomial" OR "HAl" & iii. Top 10 principal \\
OR "hospital OR & reference article \\
"healthcare" OR "health & \\
care-acquired infection" & \\
OR "Prevention" & \\
OR "Surveillance" OR & \\
"Risk" OR "risk & \\
assessment" OR "risk & \\
management" OR & \\
"Stakeholder") & \\
in the titles/abstracts & \\
\hline
\end{tabular}

\section{Methodology}

This section details the process used in the information search procedure, as well as techniques for data analysis.

\section{Data Source and Search Strategy}

Bibliometric analysis was performed using the Scopus database as of January 2021. The Boolean strings selected were "asset management" OR "maintenance management" OR "facilities management" OR "facility management", contained in the titles of articles in Scopus search engine to search for relevant articles published on asset management. The article titles were emphasised because these are the first elements readers will observe (Jamali \& Nikzad, 2011). The topics represented by the subjects of this study are important in the field of research and the study goals. No date was set limiting the start of the search, which enabled the search engine to find the earliest publications in the literature. The reviewers decided to follow the Preferred Reporting Items for Systematic Reviews and Meta-Analyses (PRISMA) guidelines for conducting systematic reviews of research. As shown in Figure 1, the initial search found 6,220 documents.

The documents from the year $2021(n=36)$ were excluded because this study aimed to analyse documents up to 2020. The subject areas included in this study consisted of Engineering, Business, Management and Accounting, Social Sciences, Economics, Econometrics Finance, and Multidisciplinary; other subject areas $(n=1390)$ were eliminated. The study focused on document types that were journal articles and conference papers; so other documents $(n=604)$ were excluded at this stage. After reviewing all the titles, no further filtering was done because the list contained items relevant to the topic. The final database for this study included 4,190 documents on asset management. 
Vol. 11, No. 3, 2021, E-ISSN: 2225-8329 @ 2021 HRMARS

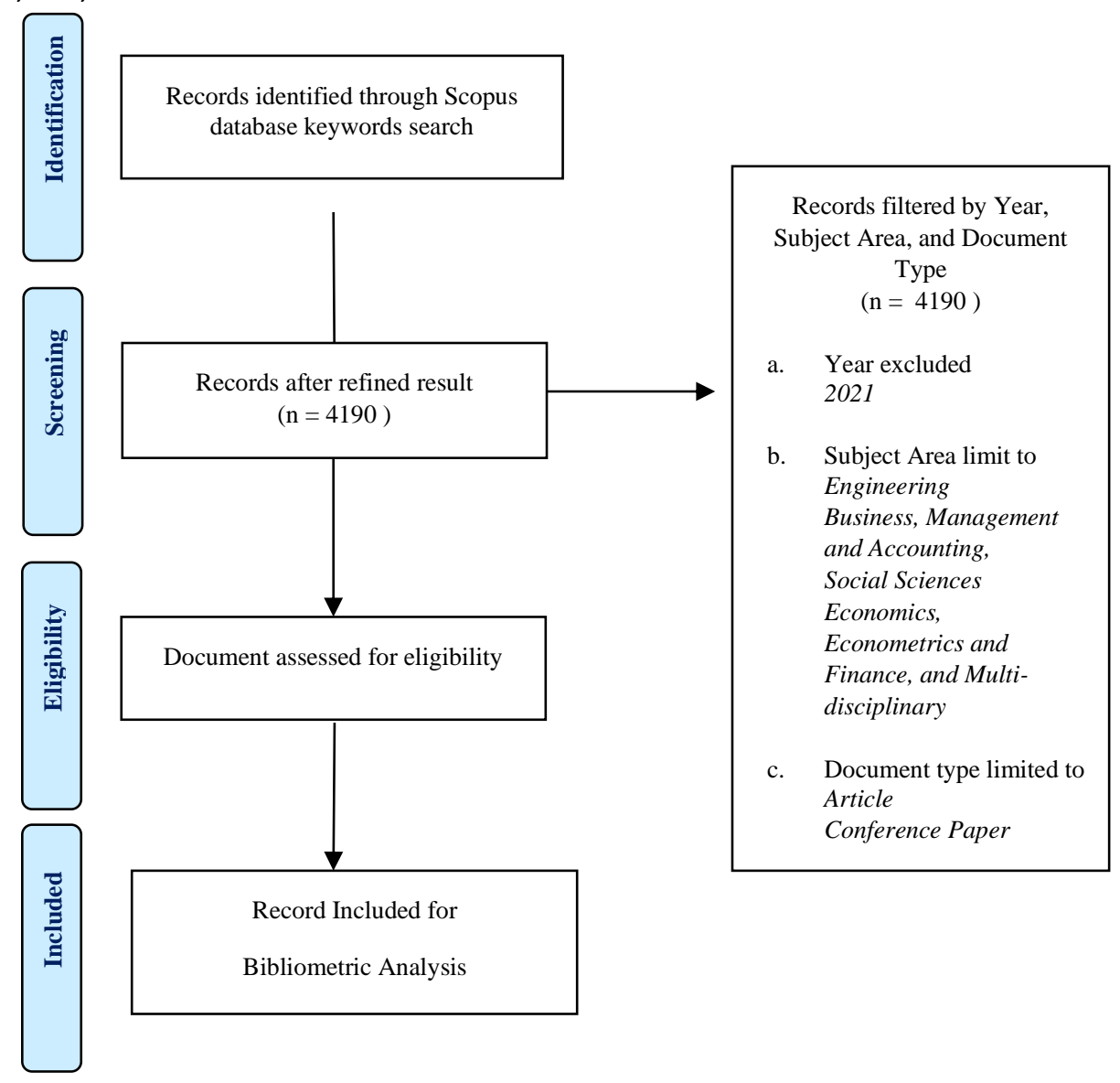

Figure 1. PRISMA flow-chart outlining search of sources for asset management research analysis

\section{Analysis of Retrieved Literature}

The information assessed for this analysis consisted of bibliographic material that described the features of 4,190 Scopus-indexed documents. This information contained author names, titles, dates of publication, and affiliations of authors to documents, as well as extensive citation details. Descriptive statistics were used to perform trend analyses about the growth and distribution of asset management literature.

The research was conducted using various software packages, including Microsoft Excel 2021, Harzing's Publish and Perish, and VOS-viewer (version 1.6.15), to assist in producing extensive analysis, creating graphs and visualising the pattern analysis. For instance, Microsoft Excel was used to measure the frequencies and percentages of the published content and to produce the related charts and graphs. Meanwhile, Harzing's Publish and Perish was used to calculate the citation metrics, and VOS-viewer helped to construct and visualise the bibliometric networks, and synthesise the patterns of information output in the chosen format.

\section{Results}

This section provides the results from the bibliometric analysis that were relevant to the research questions. Thus, details of the evolution and distribution of asset management research, the key 
INTERNATIONAL JOURNAL OF ACADEMIC RESEARCH IN ACCOUNTING, FINANCE AND MANAGEMENT SCIENCES

Vol. 11, No. 3, 2021, E-ISSN: 2225-8329 @ 2021 HRMARS

areas of asset management research, and major players and collaborations in asset management research will be discussed.

\section{Evolution and Distribution of Asset Management Research}

The evolution of asset management research and trends in its dissemination were analysed using the data of (a) growth of publications, (b) source title, (c) document and source type, and (d) document language.

\section{Analysis of Publication Growth}

An estimated 4,190 Scopus-indexed publications have been released over the past 56 years, as shown in Figure 2. This reflects a steadily increasing body of knowledge relevant to asset management. Progress in asset management research was made from the 1960s to the early 1990s, but this accelerated in the early 2000 s with the release of 1,154 papers. The majority of this literature was published between 2010 and 2020, which comprised 56\% of the total and amounted to 2,364 publications; therefore, it can be inferred that the literature is rapidly evolving.

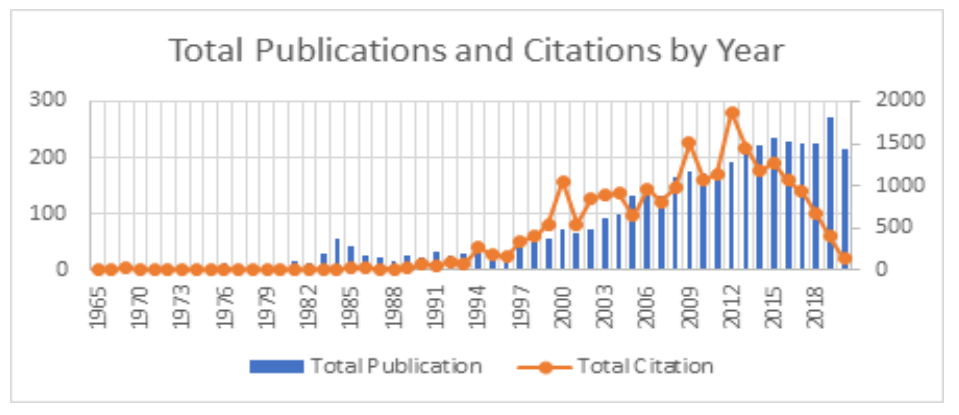

Figure 2. Growth of publications

The highest number of documents, 270 , was published in 2019 , while the documents published in $2011(1,874)$ have been cited most often over the 56 -year period. Table 2 shows the top 10 publications on asset management by year.

Table 2. Top 10 Publications by Year

\begin{tabular}{lcccccccc}
\hline No & Year & TP & CP & TC & C/P & C/CP & $\boldsymbol{h}$ & $\boldsymbol{g}$ \\
\hline 1 & 2019 & 270 & 132 & 400 & 1.48 & 3.03 & 9 & 11 \\
2 & 2015 & 235 & 144 & 1272 & 5.41 & 8.83 & 17 & 30 \\
3 & 2016 & 227 & 143 & 1062 & 4.68 & 7.43 & 18 & 25 \\
4 & 2018 & 226 & 139 & 667 & 2.95 & 4.80 & 12 & 18 \\
5 & 2017 & 224 & 146 & 935 & 4.17 & 6.40 & 15 & 22 \\
6 & 2014 & 222 & 128 & 1172 & 5.28 & 9.16 & 17 & 27 \\
7 & 2020 & 214 & 61 & 134 & 0.63 & 2.20 & 5 & 6 \\
8 & 2013 & 210 & 120 & 1456 & 6.93 & 12.13 & 19 & 32 \\
9 & 2012 & 193 & 112 & 1874 & 9.71 & 16.73 & 22 & 40 \\
10 & 2009 & 175 & 113 & 1511 & 8.63 & 13.37 & 21 & 35 \\
\hline
\end{tabular}

Notes: TP=Total Publications; $\mathrm{CP}=$ Cited publications; $\mathrm{TC}=$ Total citations; $\mathrm{C} / \mathrm{P}=$ average citations per publication; $\mathrm{C} / \mathrm{CP}=$ average citations per cited publication; $\mathrm{h}=\mathrm{h}$-index; and $\mathrm{g}=\mathrm{g}$-index. 
INTERNATIONAL JOURNAL OF ACADEMIC RESEARCH IN ACCOUNTING, FINANCE AND MANAGEMENT SCIENCES

Vol. 11, No. 3, 2021, E-ISSN: 2225-8329 @ 2021 HRMARS

\section{Analysis of Source Titles}

The journal Facilities contributed the greatest number of publications on asset management, 231 documents. This was followed by the IET Conference Publications, which produced 122 documents, and the Transportation Research Record with 86 documents. However, the source with the highest quality and reputation and the highest Cite Score, SJR 2019 and SNIP 2019, belonged to Automation In Construction. The details of the most active source titles are shown in Table 3.

Table 3. Most Active Source Titles

\begin{tabular}{|c|c|c|c|c|c|c|}
\hline Source Title & TP & $\mathrm{TC}$ & Publisher & $\begin{array}{l}\text { Cite } \\
\text { Score }\end{array}$ & $\begin{array}{c}\text { SJR } \\
2019\end{array}$ & $\begin{array}{l}\text { SNIP } \\
2019\end{array}$ \\
\hline Facilities & 231 & 2972 & $\begin{array}{l}\text { Emerald Group } \\
\text { Publishing Ltd. }\end{array}$ & 2.1 & 0.399 & 0.933 \\
\hline IET Conference Publications & 122 & 64 & $\begin{array}{l}\text { Institution of } \\
\text { Engineering and } \\
\text { Technology }\end{array}$ & N/A & N/A & $\mathrm{N} / \mathrm{A}$ \\
\hline $\begin{array}{l}\text { Transportation Research } \\
\text { Record }\end{array}$ & 86 & 338 & SAGE Publications Ltd & 1.8 & 0.54 & 0.786 \\
\hline $\begin{array}{l}\text { Journal Of Facilities } \\
\text { Management }\end{array}$ & 76 & 736 & $\begin{array}{l}\text { Emerald Group } \\
\text { Publishing Ltd. }\end{array}$ & 2.1 & 0.334 & 1.028 \\
\hline $\begin{array}{l}\text { Lecture Notes In Mechanical } \\
\text { Engineering }\end{array}$ & 40 & 25 & Springer Nature & 0.5 & 0.165 & 0.275 \\
\hline $\begin{array}{l}\text { Journal Of Quality In } \\
\text { Maintenance Engineering }\end{array}$ & 35 & 1232 & $\begin{array}{l}\text { Emerald Group } \\
\text { Publishing Ltd. }\end{array}$ & 2.0 & 0.417 & 1.28 \\
\hline $\begin{array}{l}\text { Proceedings Annual } \\
\text { Conference Canadian Society } \\
\text { For Civil Engineering }\end{array}$ & 35 & 26 & $\begin{array}{l}\text { Canadian Society for } \\
\text { Civil Engineering }\end{array}$ & N/A & N/A & $\mathrm{N} / \mathrm{A}$ \\
\hline IET Seminar Digest & 30 & 10 & $\begin{array}{l}\text { Institution of } \\
\text { Engineering and } \\
\text { Technology }\end{array}$ & N/A & N/A & N/A \\
\hline $\begin{array}{l}\text { Proceedings Of The 1st World } \\
\text { Congress On Engineering Asset } \\
\text { Management (WCEAM) } 2006\end{array}$ & 27 & 73 & $\begin{array}{l}\text { Springer-Verlag London } \\
\text { Ltd }\end{array}$ & N/A & N/A & $\mathrm{N} / \mathrm{A}$ \\
\hline Property Management & 26 & 265 & $\begin{array}{l}\text { Emerald Group } \\
\text { Publishing Ltd. }\end{array}$ & 1.3 & 0.29 & 0.982 \\
\hline $\begin{array}{l}\text { Applied Mechanics And } \\
\text { Materials }\end{array}$ & 25 & 18 & Scitec Publications Ltd. & N/A & N/A & $\mathrm{N} / \mathrm{A}$ \\
\hline Procedia Engineering & 25 & 322 & Elsevier Ltd & 2.7 & 0.316 & 1.333 \\
\hline Automation In Construction & 24 & 854 & Elsevier Ltd & 9.5 & 1.69 & 2.681 \\
\hline $\begin{array}{l}\text { lop Conference Series } \\
\text { Materials Science And } \\
\text { Engineering }\end{array}$ & 24 & 7 & $\begin{array}{l}\text { Institute of Physics } \\
\text { Publishing }\end{array}$ & 0.6 & 0.198 & 0.543 \\
\hline
\end{tabular}


INTERNATIONAL JOURNAL OF ACADEMIC RESEARCH IN ACCOUNTING, FINANCE AND MANAGEMENT SCIENCES

Vol. 11, No. 3, 2021, E-ISSN: 2225-8329 @ 2021 HRMARS

\begin{tabular}{|c|c|c|c|c|c|c|}
\hline $\begin{array}{l}\text { Advances In Intelligent } \\
\text { Systems And Computing }\end{array}$ & 23 & 105 & Springer Nature & 0.9 & 0.184 & 0.429 \\
\hline $\begin{array}{l}\text { Built Environment Project And } \\
\text { Asset Management }\end{array}$ & 22 & 230 & $\begin{array}{l}\text { Emerald Group } \\
\text { Publishing Ltd. }\end{array}$ & 1.9 & 0.379 & 0.89 \\
\hline IEE Conference Publication & 22 & 24 & $\begin{array}{l}\text { Institution of } \\
\text { Engineering and } \\
\text { Technology }\end{array}$ & N/A & 0.101 & $\mathrm{~N} / \mathrm{A}$ \\
\hline VDI Berichte & 22 & 8 & $\begin{array}{l}\text { Deutscher Ingenieur- } \\
\text { Verlag }\end{array}$ & N/A & 0.113 & $\mathrm{~N} / \mathrm{A}$ \\
\hline $\begin{array}{l}\text { Engineering Asset Lifecycle } \\
\text { Management Proceedings Of } \\
\text { The 4th World Congress On } \\
\text { Engineering Asset } \\
\text { Management (WCEAM) } 2009\end{array}$ & 20 & 63 & N/A & N/A & N/A & $\mathrm{N} / \mathrm{A}$ \\
\hline
\end{tabular}

\section{Analysis of Document and Source Types}

The published documents in the data sets were also evaluated based on the "document types" and "source types". "Document types" were based on the originality of the documents, and included book series, conference proceedings, and journal articles, whereas "source types" refers to the source documents, such as books, book chapters, conference papers, and journals. This study focused on journal articles and conference papers (Sweileh et al., 2017) because these generally give a more recent perspective and have integrity because of the peer review process, in which sources are reviewed by experts in the field before publication. The total number of conference papers indexed in Scopus was 2,009 documents, or 47.95\%; while the number of journal articles was 2,181 documents, or $52.15 \%$, as shown in Table 4.

Table 4. Document Types

\begin{tabular}{lcc}
\hline Document Type & Total Publications (TP) & Percentage (\%) \\
\hline Articles & 2181 & $52.05 \%$ \\
Conference Papers & 2009 & $47.95 \%$ \\
\hline Total & $\mathbf{4 1 9 0}$ & $\mathbf{1 0 0 . 0 0 \%}$ \\
\hline
\end{tabular}

As shown in Figure 3, the documents were categorised into six different source groups. The journals make up the largest of these, with 1,937 documents or $46.23 \%$ of the total number of documents. This group was followed by conference proceedings, book series, trade journals, books, and undefined documents. 


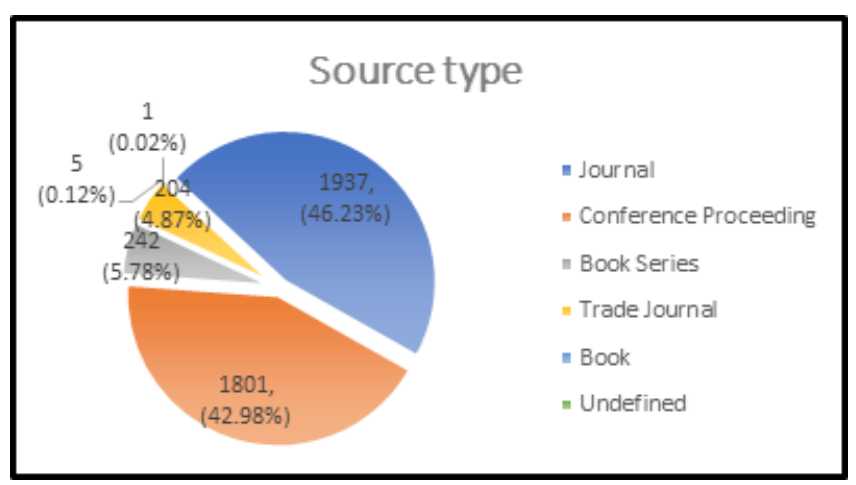

Figure 3. Total Publications per source type

\section{Analysis of the Document Language}

The languages used in the publications on asset management research are shown in Table 5. English was the most common language used in the publications obtained, comprising $92.73 \%$ of the total documents. Documents were also published in other languages, such as German, Chinese, Spanish, and French. Thirty-two publications were written in dual languages.

Table 5. List of publication languages

\begin{tabular}{lcc}
\hline Language & Total Publications (TP) & Percentage (\%) \\
\hline English & 3915 & $92.73 \%$ \\
German & 67 & $1.59 \%$ \\
Chinese & 47 & $1.11 \%$ \\
Spanish & 29 & $0.69 \%$ \\
French & 24 & $0.57 \%$ \\
Japanese & 16 & $0.38 \%$ \\
Czech & 11 & $0.26 \%$ \\
Portuguese & 10 & $0.24 \%$ \\
Polish & 5 & $0.12 \%$ \\
Russian & 5 & $0.12 \%$ \\
Serbian & 5 & $0.12 \%$ \\
Ukrainian & 5 & $0.12 \%$ \\
Italian & 5 & $0.09 \%$ \\
Croatian & 4 & $0.07 \%$ \\
Korean & 3 & $0.07 \%$ \\
Dutch & 3 & $0.02 \%$ \\
Lithuanian & 1 & $0.02 \%$ \\
Turkish & 1 & $0.02 \%$ \\
Undefined & 1 & $1.66 \%$ \\
\hline Total & 70 & $\mathbf{1 0 0 . 0 0}$ \\
\hline
\end{tabular}


INTERNATIONAL JOURNAL OF ACADEMIC RESEARCH IN ACCOUNTING, FINANCE AND

MANAGEMENT SCIENCES

Vol. 11, No. 3, 2021, E-ISSN: 2225-8329 @ 2021 HRMARS

*32 documents were prepared in dual languages

The Key Areas of Asset Management Research

The key research areas of asset management were analysed according to two criteria: (a) main subject areas, and (b) frequency of keywords.

\section{Analysis of Subject Areas}

The categories of publications were summarised based on their subject area, as shown in Table 6. Since asset management involves various disciplines, mainly Engineering. This subject area represented $81 \%$ and produced the highest number of total publications. This was followed by the Business, Management and Accounting subject areas, representing $18.52 \%$ of the total publications. Additionally, the other significant subject areas in asset management research include Computer Science, Energy, and Environmental Science.

Table 6. List of Subject Areas

\begin{tabular}{lcc}
\hline Subject Area & Total Publications (TP) & Percentage (\%) \\
\hline Engineering & 3393 & $80.98 \%$ \\
Business, Management and Accounting & 776 & $18.52 \%$ \\
Computer Science & 585 & $13.96 \%$ \\
Energy & 303 & $7.23 \%$ \\
Environmental Science & 220 & $5.25 \%$ \\
Decision Sciences & 203 & $4.84 \%$ \\
Economics, Econometrics and Finance & 194 & $4.63 \%$ \\
Materials Science & 163 & $3.89 \%$ \\
Earth and Planetary Sciences & 138 & $3.29 \%$ \\
Mathematics & 128 & $3.05 \%$ \\
Chemical Engineering & 111 & $2.65 \%$ \\
Agricultural and Biological Sciences & 40 & $0.95 \%$ \\
Chemistry & 31 & $0.74 \%$ \\
Medicine & 30 & $0.72 \%$ \\
Arts and Humanities & 25 & $0.60 \%$ \\
Multidisciplinary & 15 & $0.36 \%$ \\
Biochemistry, Genetics and Molecular & 14 & $0.33 \%$ \\
Biology & & $0.12 \%$ \\
Health Professions & 5 & $0.05 \%$ \\
Immunology and Microbiology & 2 & $0.02 \%$ \\
Neuroscience & 1 & \\
\hline
\end{tabular}

*Total publications were categorised based on the source title. In the list above, some titles are classified in several subject areas.

\section{Analysis of Top Keywords}

The keyword frequency analysis is critical to finding the current topics and developments that apply to a specific field (Wang et al., 2018). In order to make the results more understandable, this study 
INTERNATIONAL JOURNAL OF ACADEMIC RESEARCH IN ACCOUNTING, FINANCE AND MANAGEMENT SCIENCES

Vol. 11, No. 3, 2021, E-ISSN: 2225-8329 (c) 2021 HRMARS

pre-treated the original data and listed it as shown in Table 7. The top keywords appearing in the asset management research included "Asset Management", "Maintenance", "Decision-Making", "Information Management", and "Facilities Management".

Table 7. List of Top Keywords

\begin{tabular}{lcc}
\hline Author Keywords & Total Publications (TP) & Percentage (\%) \\
\hline Asset Management & 1234 & $29.45 \%$ \\
Maintenance & 900 & $21.48 \%$ \\
Decision-Making & 402 & $9.59 \%$ \\
Maintenance Management & 381 & $9.09 \%$ \\
Information Management & 353 & $8.42 \%$ \\
Facilities Management & 326 & $7.78 \%$ \\
Life Cycle & 280 & $6.68 \%$ \\
Management & 255 & $6.09 \%$ \\
Facility Management & 224 & $5.35 \%$ \\
Office Buildings & 219 & $5.23 \%$ \\
Costs & 180 & $4.30 \%$ \\
Investments & 169 & $4.03 \%$ \\
Facilities & 161 & $3.84 \%$ \\
Asset Management Systems & 159 & $3.79 \%$ \\
Risk Assessment & 154 & $3.68 \%$ \\
Reliability & 152 & $3.63 \%$ \\
Decision Support Systems & 150 & $3.58 \%$ \\
Project Management & 149 & $3.56 \%$ \\
Preventive Maintenance & 145 & $3.46 \%$ \\
Highway Administration & 140 & $3.34 \%$ \\
\hline A tot of & &
\end{tabular}

A total of 16,215 keywords were found after analysing a series of data management processes. To scientifically quantify the key research hotspots in this field, Vosviewer was used to construct an analysis map of the co-occurrence of all keywords, as shown in Figure 4. The nodes drawn represent a keyword; the larger nodes indicate the occurrence of keywords at a higher frequency. Conversely, the presence of links indicates the frequency of keyword co-occurrences; a thicker link represents a higher frequency of keyword co-occurrences. 


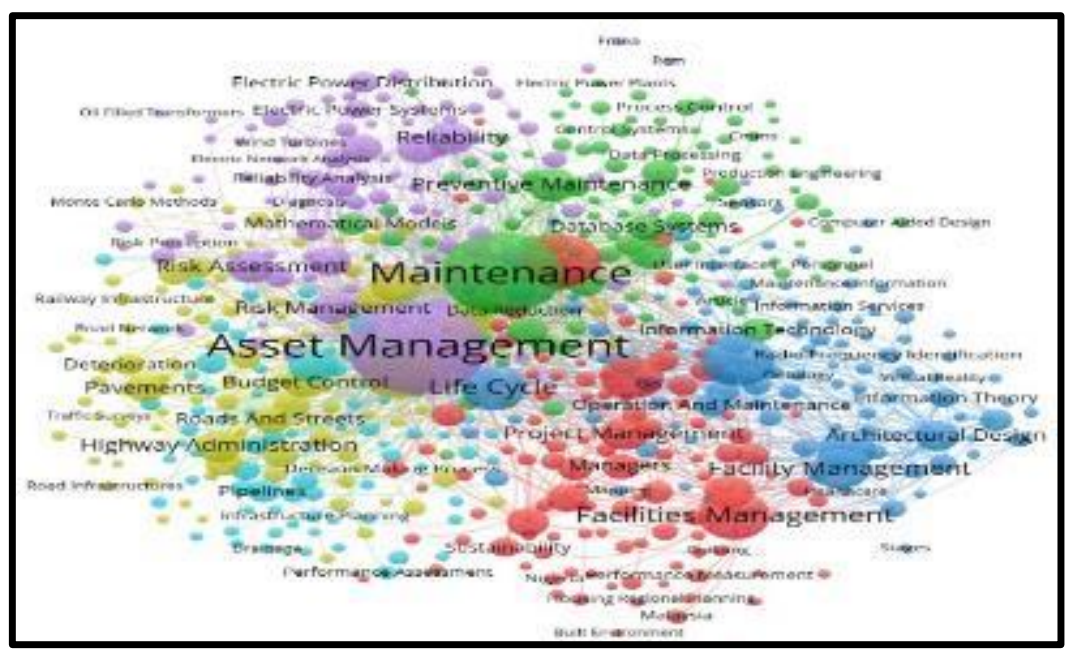

Figure 4. A visualisation map of the keyword co-occurrence network

\section{Major Players and Collaborations in Asset Management Research}

To examine the prominent individuals in asset management research and their collaborations with various authors in different countries, analysis was conducted of several criteria including (a) authorship analysis, (b) countries contributing most to asset management research, (c) the main institutions involved in asset management research, and (d) citations analysis.

\section{Analysis of Authorship}

The number of authors per published document on asset management research is shown in Table 8. As previously mentioned, a total of 4,190 research papers were included in this study. Singleauthored publications made up $27.52 \%$ of the total number of publications found, while $70.76 \%$ of the publications were multi-authored. Seventy-two (1.72\%) publications from conference review documents did not list authors.

Table 8. Number of Author(s) per document

\begin{tabular}{lll}
\hline Author Count & Total Publications (TP) & Percentage (\%) \\
\hline 1 & 1153 & 27.52 \\
2 & 1135 & 27.09 \\
3 & 889 & 21.22 \\
4 & 526 & 12.55 \\
5 & 232 & 5.54 \\
6 & 102 & 2.43 \\
7 & 44 & 1.05 \\
8 & 15 & 0.36 \\
9 & 11 & 0.26 \\
10 & 1 & 0.02 \\
11 & 4 & 0.10 \\
12 & 1 & 0.02 \\
14 & 1 & 0.02 \\
16 & 1 & 0.02 \\
18 & 1 & 0.02 \\
21 & 1 & 0.02 \\
23 & 1 & 0.02 \\
$0^{*}$ & 72 & 1.72 \\
\hline Total & 4190 & 100.00 \\
\hline
\end{tabular}

\footnotetext{
*Conference review document. No author listed.
} 
INTERNATIONAL JOURNAL OF ACADEMIC RESEARCH IN ACCOUNTING, FINANCE AND MANAGEMENT SCIENCES

Vol. 11, No. 3, 2021, E-ISSN: 2225-8329 @ 2021 HRMARS

Meanwhile, Table 9 shows the most productive authors contributing to asset management research. The number of publications issued by an author can be used to gauge their productivity in a particular research area (Bottle et al., 1994). Sixteen authors published the most documents on asset management, with ten or more publications each. The top three most productive authors by publication were Pitt, M. (23 publications) from The Bartlett Faculty of the Built Environment, United Kingdom; second was Koronios, A. (18 publications), affiliated with the University of South Australia; and the third most productive author publishing on asset management was Andrews, J.D. (17 publications), from the University of Nottingham, United Kingdom. However, documents produced by Baldry, D. from the University of Salford, United Kingdom, were cited most often (22.54 citations per paper). Most authors in asset management studies came from developed countries, except Kamaruzzaman, S.N and Sapri, M., who came from Malaysia.

Table 9. List of Most Productive Authors

\begin{tabular}{|c|c|c|c|c|c|c|c|c|c|}
\hline $\begin{array}{l}\text { Author } \\
\text { Name }\end{array}$ & Affiliation & Country & TP & NCP & $\mathrm{TC}$ & $C / P$ & $\mathrm{C} / \mathrm{CP}$ & $\boldsymbol{h}$ & $g$ \\
\hline Pitt, M. & $\begin{array}{l}\text { The Bartlett } \\
\text { Faculty of the } \\
\text { Built Environment }\end{array}$ & $\begin{array}{l}\text { United } \\
\text { Kingdom }\end{array}$ & 23 & 23 & 475 & $\begin{array}{c}20.6 \\
5\end{array}$ & 20.65 & 13 & 21 \\
\hline Koronios, A. & $\begin{array}{l}\text { University of } \\
\text { South Australia }\end{array}$ & Australia & 18 & 14 & 88 & 4.89 & 6.29 & 5 & 9 \\
\hline $\begin{array}{l}\text { Andrews, } \\
\text { J.D. }\end{array}$ & $\begin{array}{l}\text { University of } \\
\text { Nottingham }\end{array}$ & $\begin{array}{l}\text { United } \\
\text { Kingdom }\end{array}$ & 17 & 14 & 221 & $\begin{array}{c}13.0 \\
0\end{array}$ & 15.79 & 7 & 14 \\
\hline Anon & $\begin{array}{l}\text { United States } \\
\text { Army }\end{array}$ & $\begin{array}{l}\text { United } \\
\text { States }\end{array}$ & 16 & 0 & 0 & 0.00 & 0.00 & 0 & 0 \\
\hline Tighe, S.L. & $\begin{array}{l}\text { University of } \\
\text { Waterloo, }\end{array}$ & Canada & 16 & 6 & 9 & 0.56 & 1.50 & 2 & 2 \\
\hline Baldry, D. & $\begin{array}{l}\text { University of } \\
\text { Salford }\end{array}$ & $\begin{array}{l}\text { United } \\
\text { Kingdom }\end{array}$ & 13 & 10 & 293 & $\begin{array}{c}22.5 \\
4\end{array}$ & 29.30 & 8 & 13 \\
\hline Vlok, P.J. & $\begin{array}{l}\text { The University of } \\
\text { Tennessee, } \\
\text { Knoxville }\end{array}$ & $\begin{array}{l}\text { United } \\
\text { States }\end{array}$ & 13 & 12 & 40 & 3.08 & 3.33 & 3 & 5 \\
\hline Gao, J. & $\begin{array}{l}\text { University of } \\
\text { South Australia }\end{array}$ & $\begin{array}{l}\text { Adelaide, } \\
\text { Australia }\end{array}$ & 12 & 10 & 58 & 4.83 & 5.80 & 4 & 7 \\
\hline Lavy, S. & $\begin{array}{l}\text { Texas A\&M } \\
\text { University, } \\
\text { College Station, }\end{array}$ & $\begin{array}{l}\text { United } \\
\text { States }\end{array}$ & 12 & 10 & 231 & $\begin{array}{c}19.2 \\
5\end{array}$ & 23.10 & 9 & 12 \\
\hline Haider, A. & $\begin{array}{l}\text { University of } \\
\text { South Australia }\end{array}$ & Australia & 11 & 6 & 39 & 3.55 & 6.50 & 3 & 6 \\
\hline $\begin{array}{l}\text { Kamaruzzam } \\
\text { an, S.N. }\end{array}$ & $\begin{array}{l}\text { University of } \\
\text { Malaya }\end{array}$ & Malaysia & 11 & 10 & 86 & 7.82 & 8.60 & 5 & 9 \\
\hline McNeil, S. & $\begin{array}{l}\text { University of } \\
\text { Delaware }\end{array}$ & $\begin{array}{l}\text { United } \\
\text { States }\end{array}$ & 11 & 8 & 63 & 5.73 & 7.88 & 5 & 7 \\
\hline
\end{tabular}


INTERNATIONAL JOURNAL OF ACADEMIC RESEARCH IN ACCOUNTING, FINANCE AND MANAGEMENT SCIENCES

Vol. 11, No. 3, 2021, E-ISSN: 2225-8329 @ 2021 HRMARS

\begin{tabular}{llllllllll}
\hline Sapri, M. & $\begin{array}{l}\text { Universiti } \\
\text { Teknologi } \\
\text { Malaysia }\end{array}$ & Malaysia & 11 & 9 & 49 & 4.45 & 5.44 & 5 & 6 \\
\hline Schwan, M. & $\begin{array}{l}\text { Siemens AG, } \\
\text { Munich }\end{array}$ & Germany & 11 & 7 & 159 & $\begin{array}{c}14.4 \\
5\end{array}$ & 22.71 & 4 & 11 \\
\hline Alexander, K. & $\begin{array}{l}\text { Centre for } \\
\text { Facilities } \\
\text { Management, } \\
\text { Manchester }\end{array}$ & $\begin{array}{l}\text { United } \\
\text { Kingdom }\end{array}$ & 10 & 10 & 110 & $\begin{array}{c}11.0 \\
0\end{array}$ & 11.00 & 6 & 10 \\
\hline Elmualim, A. & $\begin{array}{l}\text { Constructing } \\
\text { Futures, Adelaide }\end{array}$ & Australia & 10 & 7 & 198 & $\begin{array}{c}19.8 \\
0\end{array}$ & 28.29 & 6 & 10 \\
\hline
\end{tabular}

Notes: TP=total number of publications; $\mathrm{NCP}=$ number of cited publications; TC=total citations;

$\mathrm{C} / \mathrm{P}=$ average citations per publication; $\mathrm{C} / \mathrm{CP}=$ average citations per cited publication; $\mathrm{h}=\mathrm{h}$-index; and $\mathrm{g}=\mathrm{g}$-index.

The network visualisation made with VOSviewer software displays the mapping of co-authorship between various authors. The mapping was constructed using the fractional counting method and data from authors with at least two documents on asset management. The strength of the relationship is indicated by the colour, size, font size, and thickness of connecting lines. Related authors are commonly listed together with the same colour used to denote them. For example, in Figure 5, the illustration demonstrates that Koronios A., Parlikad A.K., and Haider A., from the same Australian institution, worked together closely. Meanwhile, Liu $Y$ appeared to have numerous collaborations with authors from all over the world.

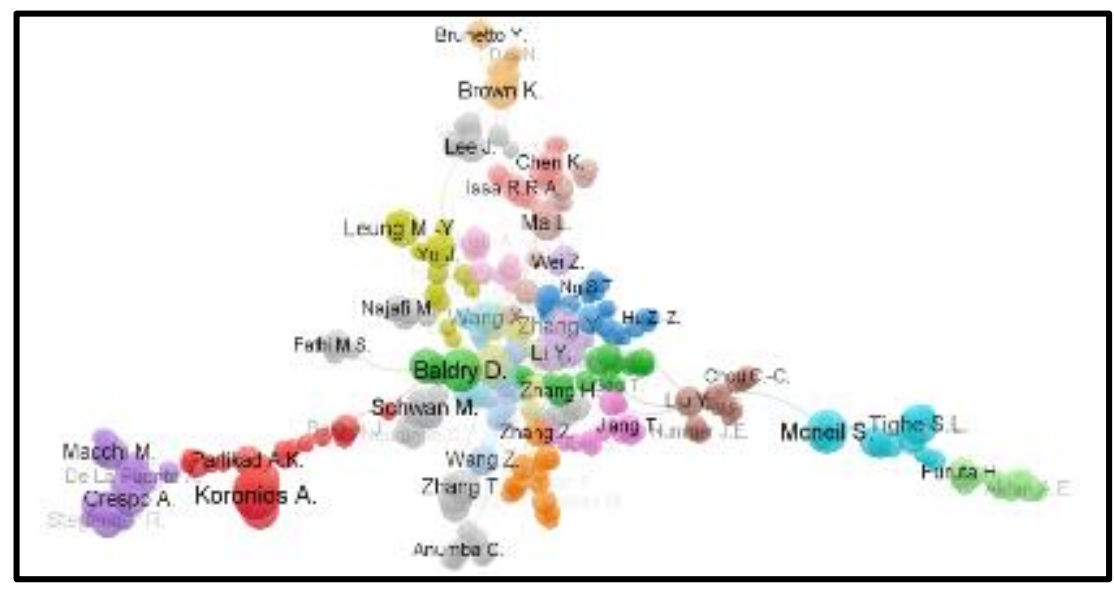

Figure 5. A visualisation map of co-authorship networks

The network visualisation map of the authors based on the countries with which they were affiliated is shown in Figure 6. In order to ensure the results were statistically relevant, only countries with at least five documents and at least five citations were included in this analysis. Using the full counting method, the maps show that United States-based authors were at the forefront of research on asset management, in terms of collaborations with authors from other countries. The former authors 
Vol. 11, No. 3, 2021, E-ISSN: 2225-8329 @ 2021 HRMARS

closely collaborated with colleagues from the following countries: (a) Thailand, (b) Canada, (c) the Philippines, and (d) Iran. Several international collaborations were also established by authors from China, Spain, Japan, Australia, Germany and the Netherlands.

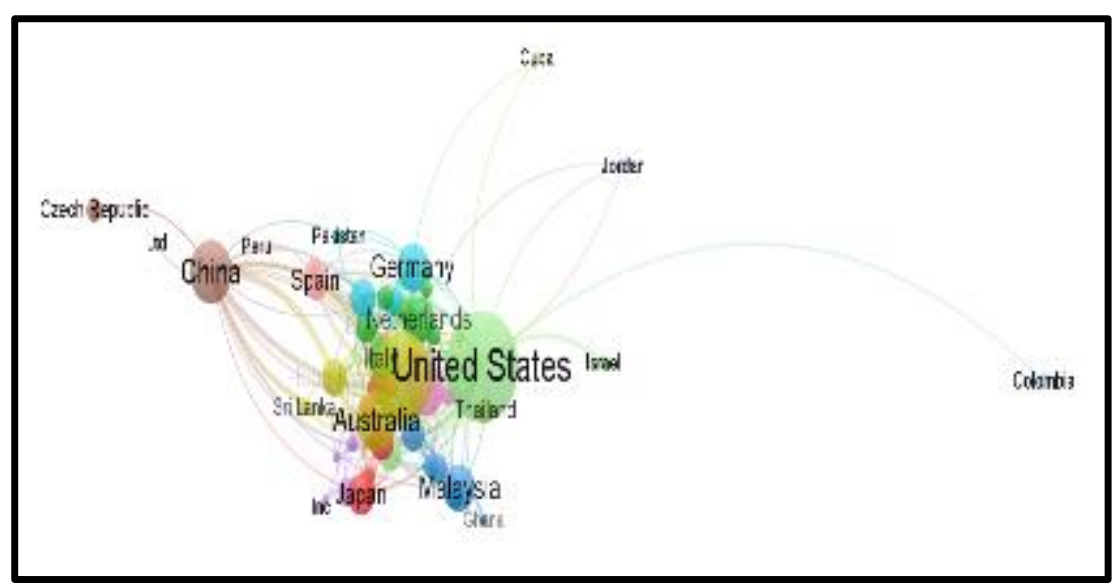

Figure 6. A visualisation map of authors based on country networks

\section{Analysis of the Countries Contributing most to Asset Management Research}

Table 10 lists the top 20 countries contributing to publications on asset management. The United States was the lead country in producing such publications, and contributed 808 documents. It was followed by the United Kingdom (523 publications), China (245 publications) and Australia (227 publications). Other countries contributed less than 200 publications. However, most documents published by Sweden were cited, meaning the country was listed as having a higher number (15.45) of citations per paper. It is evident that asset management plays a significant role in many geographical regions. 
INTERNATIONAL JOURNAL OF ACADEMIC RESEARCH IN ACCOUNTING, FINANCE AND MANAGEMENT SCIENCES

Vol. 11, No. 3, 2021, E-ISSN: 2225-8329 @ 2021 HRMARS

Table 10. List of Top 20 Countries contributing to publications

\begin{tabular}{lccccccc}
\hline Country & TP & NCP & TC & C/P & C/CP & $\boldsymbol{h}$ & $\boldsymbol{g}$ \\
\hline United States & 808 & 439 & 4810 & 5.95 & 10.96 & 32 & 53 \\
United Kingdom & 523 & 364 & 4965 & 9.49 & 13.64 & 37 & 51 \\
China & 245 & 121 & 967 & 3.95 & 7.99 & 16 & 27 \\
Australia & 227 & 162 & 1688 & 7.44 & 10.42 & 21 & 34 \\
Canada & 193 & 116 & 2054 & 10.64 & 17.71 & 23 & 42 \\
Germany & 144 & 73 & 689 & 4.78 & 9.44 & 12 & 24 \\
Malaysia & 133 & 89 & 601 & 4.52 & 6.75 & 14 & 20 \\
Netherlands & 122 & 78 & 642 & 5.26 & 8.23 & 15 & 20 \\
Italy & 98 & 74 & 704 & 7.18 & 9.51 & 14 & 23 \\
Japan & 98 & 44 & 335 & 3.42 & 7.61 & 10 & 17 \\
France & 90 & 56 & 657 & 7.30 & 11.73 & 13 & 24 \\
Spain & 86 & 61 & 885 & 10.29 & 14.51 & 17 & 28 \\
Hong Kong & 83 & 62 & 791 & 9.53 & 12.76 & 17 & 25 \\
India & 77 & 49 & 275 & 3.57 & 5.61 & 10 & 14 \\
South Africa & 67 & 43 & 261 & 3.90 & 6.07 & 8 & 14 \\
South Korea & 65 & 44 & 538 & 8.28 & 12.23 & 12 & 22 \\
Brazil & 59 & 24 & 167 & 2.83 & 6.96 & 7 & 12 \\
Sweden & 58 & 44 & 896 & 15.45 & 20.36 & 11 & 29 \\
Taiwan & 49 & 25 & 270 & 5.51 & 10.80 & 11 & 16 \\
Finland & 48 & 37 & 314 & 6.54 & 8.49 & 10 & 16
\end{tabular}

Notes: $\mathrm{TP}=$ total number of publications; $\mathrm{NCP}=$ number of cited publications; $\mathrm{TC}=$ total citations; $\mathrm{C} / \mathrm{P}=$ average citations per publication; $\mathrm{C} / \mathrm{CP}=$ average citations per cited publication; $\mathrm{h}=\mathrm{h}$-index; and g=g-index.

\section{Analysis of the Main Institutions Contributing to Asset Management Research}

Twenty-three prominent institutions produced at least 20 publications on asset management research. Out of the 4,190 documents, Delft University of Technology published 51 documents, followed by Universiti Teknologi Malaysia and the University of South Australia, which published 36 documents each. Another 20 institutions published more than 20 documents, as listed in Table 11. 
INTERNATIONAL JOURNAL OF ACADEMIC RESEARCH IN ACCOUNTING, FINANCE AND

MANAGEMENT SCIENCES

Vol. 11, No. 3, 2021, E-ISSN: 2225-8329 @ 2021 HRMARS

Table 11. List of most influential institutions with a minimum of 20 publications

\begin{tabular}{|c|c|c|c|c|c|c|c|c|}
\hline Affiliation & Country & TP & NCP & TC & $C / P$ & $\mathrm{C} / \mathrm{CP}$ & $h$ & $g$ \\
\hline $\begin{array}{l}\text { Delft University of } \\
\text { Technology }\end{array}$ & $\begin{array}{l}\text { Netherland } \\
\mathrm{s}\end{array}$ & 52 & 38 & 280 & 5.38 & 7.37 & 9 & 13 \\
\hline $\begin{array}{l}\text { Universiti Teknologi } \\
\text { Malaysia }\end{array}$ & Malaysia & 36 & 23 & 77 & 2.14 & 3.35 & 5 & 6 \\
\hline $\begin{array}{l}\text { University of South } \\
\text { Australia }\end{array}$ & Australia & 36 & 27 & 233 & 6.47 & 8.63 & 9 & 14 \\
\hline $\begin{array}{l}\text { Queensland University of } \\
\text { Technology }\end{array}$ & Australia & 33 & 24 & 243 & 7.36 & 10.13 & 7 & 15 \\
\hline University of Salford & $\begin{array}{l}\text { United } \\
\text { Kingdom }\end{array}$ & 32 & 27 & 524 & 16.38 & 19.41 & 14 & 22 \\
\hline $\begin{array}{l}\text { Hong Kong Polytechnic } \\
\text { University }\end{array}$ & Hong Kong & 32 & 27 & 472 & 14.75 & 17.48 & 11 & 21 \\
\hline $\begin{array}{l}\text { Georgia Institute of } \\
\text { Technology }\end{array}$ & $\begin{array}{l}\text { United } \\
\text { States }\end{array}$ & 31 & 27 & 440 & 14.19 & 16.30 & 10 & 20 \\
\hline $\begin{array}{l}\text { Heriot-Watt University, } \\
\text { Edinburgh }\end{array}$ & $\begin{array}{l}\text { United } \\
\text { Kingdom }\end{array}$ & 30 & 27 & 521 & 17.37 & 19.30 & 12 & 22 \\
\hline $\begin{array}{l}\text { Virginia Polytechnic } \\
\text { Institute and State } \\
\text { University }\end{array}$ & $\begin{array}{l}\text { United } \\
\text { States }\end{array}$ & 27 & 20 & 346 & 12.81 & 17.30 & 8 & 15 \\
\hline University of Waterloo & Canada & 26 & 11 & 179 & 6.88 & 16.27 & 4 & 13 \\
\hline $\begin{array}{l}\text { Norges teknisk- } \\
\text { naturvitenskapelige } \\
\text { universitet }\end{array}$ & Norway & 25 & 19 & 362 & 14.48 & 19.05 & 8 & 19 \\
\hline University of Reading & $\begin{array}{l}\text { United } \\
\text { Kingdom }\end{array}$ & 24 & 19 & 364 & 15.17 & 19.16 & 10 & 19 \\
\hline Universiteit van Pretoria & $\begin{array}{l}\text { South } \\
\text { Africa }\end{array}$ & 24 & 12 & 87 & 3.63 & 7.25 & 5 & 9 \\
\hline University of Seville & Spain & 23 & 18 & 380 & 16.52 & 21.11 & 8 & 19 \\
\hline University College London & $\begin{array}{l}\text { United } \\
\text { Kingdom }\end{array}$ & 22 & 19 & 269 & 12.23 & 14.16 & 7 & 16 \\
\hline University of Malaya & Malaysia & 22 & 19 & 181 & 8.23 & 9.53 & 6 & 13 \\
\hline University of Nottingham & $\begin{array}{l}\text { United } \\
\text { Kingdom }\end{array}$ & 21 & 15 & 282 & 13.43 & 18.80 & 7 & 16 \\
\hline Politecnico di Milano & Italy & 21 & 17 & 211 & 10.05 & 12.41 & 8 & 14 \\
\hline IEEE & $\begin{array}{l}\text { United } \\
\text { States }\end{array}$ & 20 & 16 & 107 & 5.35 & 6.69 & 6 & 9 \\
\hline $\begin{array}{l}\text { Universidad de Castilla-La } \\
\text { Mancha }\end{array}$ & Spain & 20 & 17 & 303 & 15.15 & 17.82 & 10 & 17 \\
\hline Universiti Teknologi MARA & Malaysia & 20 & 16 & 93 & 4.65 & 5.81 & 6 & 8 \\
\hline
\end{tabular}


INTERNATIONAL JOURNAL OF ACADEMIC RESEARCH IN ACCOUNTING, FINANCE AND MANAGEMENT SCIENCES

Vol. 11 , No. 3, 2021, E-ISSN: $2225-8329$ @ 2021 HRMARS

\begin{tabular}{lllllllll}
\hline University of Birmingham & $\begin{array}{l}\text { United } \\
\text { Kingdom }\end{array}$ & 20 & 16 & 111 & 5.55 & 6.94 & 6 & 10 \\
\hline Concordia University & Canada & 20 & 10 & 148 & 7.40 & 14.80 & 4 & 12 \\
\hline
\end{tabular}

Notes: TP=total number of publications; $\mathrm{NCP}=$ number of cited publications; TC=total citations; $\mathrm{C} / \mathrm{P}=$ average citations per publication; $\mathrm{C} / \mathrm{CP}=$ average citations per cited publication; $\mathrm{h}=\mathrm{h}$-index; and $\mathrm{g}=\mathrm{g}$-index.

\section{Analysis of Citations}

Overall, asset management research citation metrics in Scopus, as indexed on January 31, 2021, are shown in Table 12. The information provided states that since 1965, 4,190 citations have been reported over 56 years (1965-2020) in asset management publications. The citation metric generated from Harzing's Publish and Perish software by importing the RIS formatted file from Scopus to the software was generated by importing the Scopus RIS formatted file into the software.

Table 12. Citations Metrics

\begin{tabular}{ll}
\hline Metrics & Data \\
\hline Publication years & $1965-2020$ \\
Citation years & $56(1965-2020)$ \\
Papers & 4190 \\
Citations & 22722 \\
Years & 56 \\
Cites per Year & 405.75 \\
Cites per Paper & 5.42 \\
Cites per Author & 10735.05 \\
Papers per Author & 2222.21 \\
Authors per Paper & 2.53 \\
h index & 60 \\
g index & 87 \\
\hline
\end{tabular}

Meanwhile, Table 13 details the top 20 most-cited articles on asset management research. The most cited article recorded in Scopus is entitled "Application areas and data requirements for BIM-enabled facilities management", written by B. Becerik-Gerber, F. Jazizadeh, N. Li, and G. Calis (2012), with an average of 45.44 citations per year. 
INTERNATIONAL JOURNAL OF ACADEMIC RESEARCH IN ACCOUNTING, FINANCE AND MANAGEMENT SCIENCES

Vol. 11, No. 3, 2021, E-ISSN: 2225-8329 @ 2021 HRMARS

Table 13. List of Top 20 most cited articles on Asset Management

\begin{tabular}{|c|c|c|c|c|c|}
\hline No. & Authors & Title & Year & Cites & $\begin{array}{c}\text { Cites } \\
\text { per Year }\end{array}$ \\
\hline 1 & $\begin{array}{l}\text { B. Becerik-Gerber, F. } \\
\text { Jazizadeh, N. Li, G. } \\
\text { Calis }\end{array}$ & $\begin{array}{l}\text { Application areas and data } \\
\text { requirements for BIM-enabled facilities } \\
\text { management }\end{array}$ & 2012 & 409 & 45.44 \\
\hline 2 & $\begin{array}{l}\text { C. De Vleeschouwer, } \\
\text { J.-F. Delaigle, B. } \\
\text { Macq }\end{array}$ & $\begin{array}{l}\text { Circular interpretation of bijective } \\
\text { transformations in lossless } \\
\text { watermarking for media asset } \\
\text { management }\end{array}$ & 2003 & 333 & 18.5 \\
\hline 3 & J. Nilsson, L. Bertling & $\begin{array}{l}\text { Maintenance management of wind } \\
\text { power systems using condition } \\
\text { monitoring systems - Life cycle cost } \\
\text { analysis for two case studies }\end{array}$ & 2007 & 269 & 19.21 \\
\hline 4 & $\begin{array}{l}\text { A.N. Jahromi, R. } \\
\text { Piercy, S. Cress, } \\
\text { J.R.R. Service, W. } \\
\text { Fan }\end{array}$ & $\begin{array}{l}\text { An approach to power transformer } \\
\text { asset management using health index }\end{array}$ & 2009 & 215 & 17.92 \\
\hline 5 & D. Sherwin & $\begin{array}{l}\text { A review of overall models for } \\
\text { maintenance management }\end{array}$ & 2000 & 191 & 9.1 \\
\hline 6 & $\begin{array}{l}\text { P.D. Berger, R.N. } \\
\text { Bolton, D. Bowman, } \\
\text { E. Briggs, V. Kumar, } \\
\text { A. Parasuraman, C. } \\
\text { Terry }\end{array}$ & $\begin{array}{l}\text { Marketing Actions and the Value of } \\
\text { Customer Assets: A Framework for } \\
\text { Customer Asset Management }\end{array}$ & 2002 & 153 & 8.05 \\
\hline 7 & $\begin{array}{l}\text { D.N.P. Murthy, A. } \\
\text { Atrens, J.A. } \\
\text { Eccleston }\end{array}$ & Strategic maintenance management & 2002 & 138 & 7.26 \\
\hline 8 & $\begin{array}{l}\text { A. Crespo Marquez, } \\
\text { J.N.D. Gupta }\end{array}$ & $\begin{array}{l}\text { Contemporary maintenance } \\
\text { management: Process, framework and } \\
\text { supporting pillars }\end{array}$ & 2006 & 132 & 8.8 \\
\hline 9 & $\begin{array}{l}\text { T.W. Kang, C.H. } \\
\text { Hong }\end{array}$ & $\begin{array}{l}\text { A study on software architecture for } \\
\text { effective BIM/GIS-based facility } \\
\text { management data integration }\end{array}$ & 2015 & 131 & 21.83 \\
\hline 10 & $\begin{array}{l}\text { A.E.B. Abu-Elanien, } \\
\text { M.M.A. Salama }\end{array}$ & $\begin{array}{l}\text { Asset management techniques for } \\
\text { transformers }\end{array}$ & 2010 & 126 & 11.45 \\
\hline 11 & $\begin{array}{l}\text { Schneider, J., Gaul, } \\
\text { A. J., Neumann, C., } \\
\text { Hogräfer, J., } \\
\text { Wellßow, W., } \\
\text { Schwan, M., \& } \\
\text { Schnettler, A. }\end{array}$ & Asset management techniques & 2006 & 123 & 8.2 \\
\hline
\end{tabular}


INTERNATIONAL JOURNAL OF ACADEMIC RESEARCH IN ACCOUNTING, FINANCE AND MANAGEMENT SCIENCES

Vol. 11, No. 3, 2021, E-ISSN: 2225-8329 @ 2021 HRMARS

\begin{tabular}{cllccc}
\hline 12 & $\begin{array}{l}\text { K.A. Kaiser, N.Z. } \\
\text { Gebraeel }\end{array}$ & $\begin{array}{l}\text { Predictive maintenance management } \\
\text { using sensor-based degradation models }\end{array}$ & 2009 & 122 & 10.17 \\
\hline 13 & $\begin{array}{l}\text { X. Zhang, E. } \\
\text { Gockenbach }\end{array}$ & $\begin{array}{l}\text { Asset-management of transformers } \\
\text { based on condition monitoring and } \\
\text { standard diagnosis }\end{array}$ & 2008 & 122 & 9.38 \\
\hline 14 & D.J.D. Vanier & $\begin{array}{l}\text { Why industry needs asset management } \\
\text { tools }\end{array}$ & 2001 & 121 & 6.05 \\
\hline 15 & S. Chotipanich & Positioning facility management & 2004 & 118 & 6.94 \\
\hline 16 & $\begin{array}{l}\text { M. Kassem, G. Kelly, } \\
\text { N. Dawood, M. } \\
\text { Serginson, S. Lockley }\end{array}$ & $\begin{array}{l}\text { BIM in facilities management } \\
\text { applications: A case study of a large } \\
\text { university complex }\end{array}$ & 2015 & 114 & 19 \\
\hline 17 & $\begin{array}{l}\text { A.W. Labib } \\
\text { World-class maintenance using a }\end{array}$ & $\begin{array}{l}1998 \\
\text { computerised maintenance } \\
\text { management system }\end{array}$ & 112 & 4.87 \\
\hline 18 & $\begin{array}{l}\text { W.T. Scherer, D.M. } \\
\text { Glagola }\end{array}$ & $\begin{array}{l}\text { Markovian models for bridge } \\
\text { maintenance management }\end{array}$ & 1994 & 109 & 4.04 \\
\hline 19 & $\begin{array}{l}\text { A. Motamedi, A. } \\
\text { Hammad, Y. Asen }\end{array}$ & $\begin{array}{l}\text { Knowledge-assisted BIM-based visual } \\
\text { analytics for failure root cause } \\
\text { detection in facilities management }\end{array}$ & 2014 & 108 & 15.43 \\
\hline 20 & $\begin{array}{l}\text { Y. Wang, X. Wang, J. } \\
\text { Wang, P. Yung, G. } \\
\text { Jun }\end{array}$ & $\begin{array}{l}\text { Engagement of facilities management } \\
\text { in design stage through BIM: } \\
\text { Framework and a case study }\end{array}$ & 2013 & 106 & 13.25 \\
\hline
\end{tabular}

In Figure 7, the distribution of documents with at least 20 citations is presented. It highlights various prominent authors in the field and how their ideas were interrelated. Figure 8 further details where the countries of origin are located. The United States, the United Kingdom, China, Australia, Canada, the Netherlands and Italy were perceived to be the most influential countries because asset management research authors from these countries were cited most frequently.

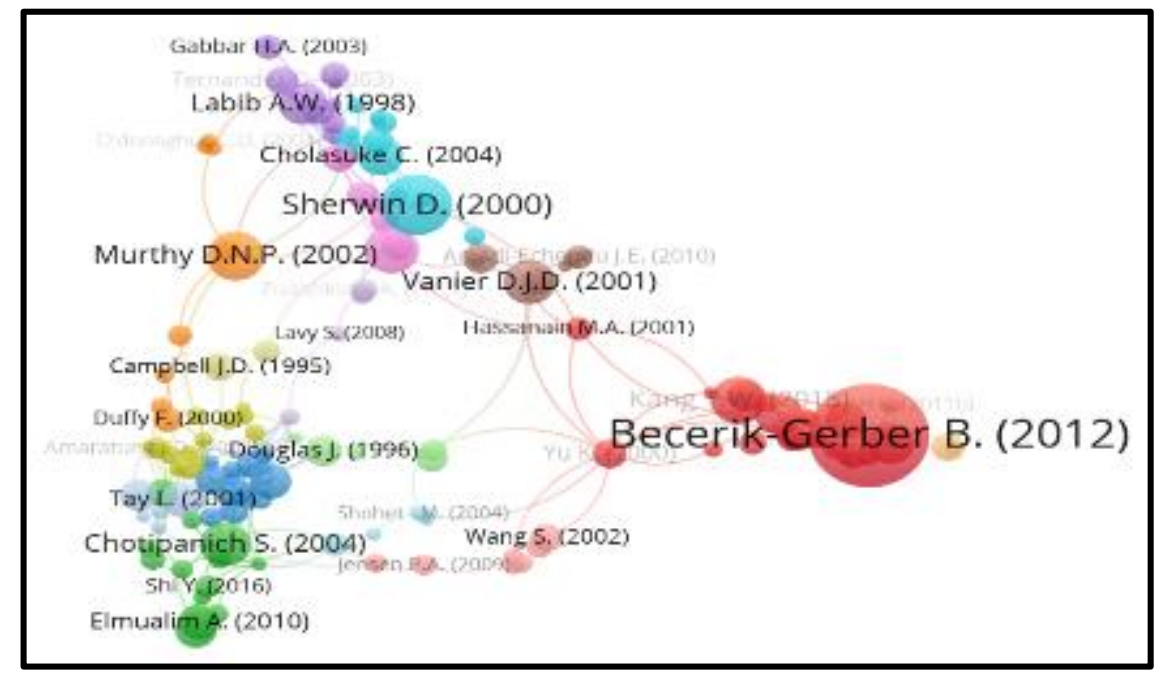

Figure 7. Network visualisation map of citations of asset management documents 


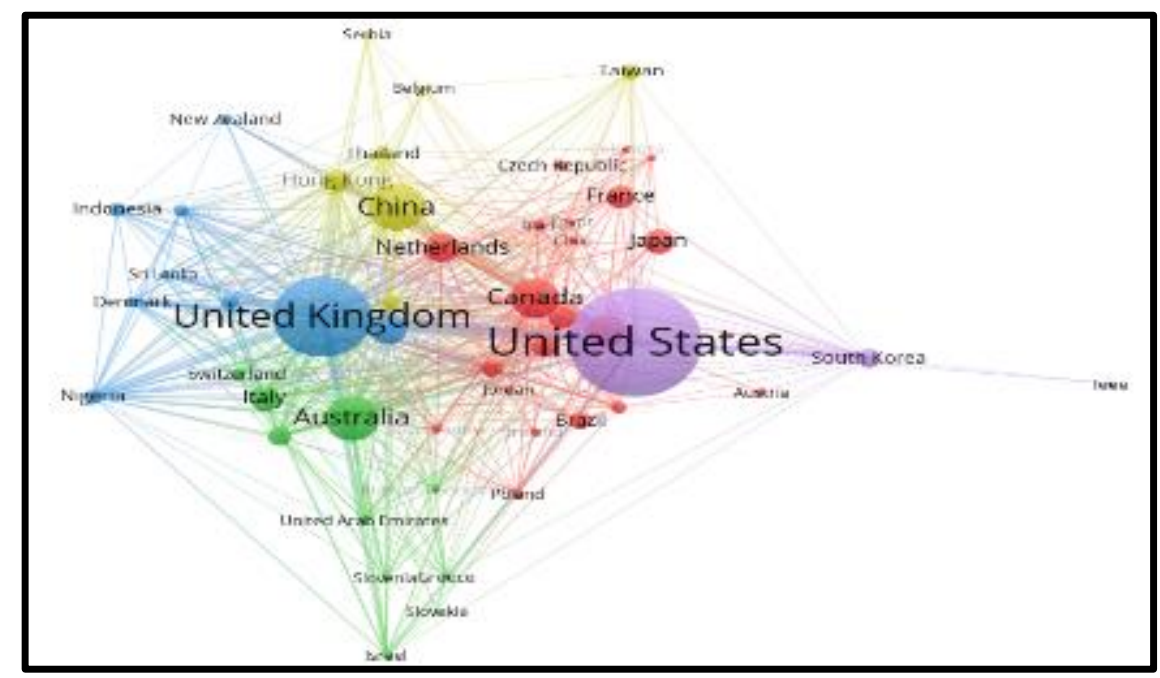

Figure 8. Network visualisation map of citations of asset management documents by country, with a minimum of ten documents per country and a minimum of ten citations per country

\section{Discussion}

This paper aims to provide a comprehensive study of the available research information related to asset management using the bibliometric analysis technique. Bibliometric analysis is an increasingly popular technique for demonstrating trends of studies (Ahmi \& Mohd Nasir, 2019). The information from the bibliometric data may be used to judge the success of a particular research domain and be beneficial for research-related agencies in regulating funding allocation policies (Gu, 2004).

This paper analysed the various publications found in the Scopus database covering asset management. This study found more than 4,190 documents from the stated database using the specified search queries. The analysis was categorised under three themes that were based on the research objectives.

\section{The Evolution and Distribution of Asset Management Research}

Documents on asset management first appeared in early 1965, published in Human Factors: The Journal of Human Factors and Ergonomics. The earliest documents on asset management were written by Haglund, Richard F. from the Collins Radio Company in the United States. In 1966, another two documents on asset management were indexed in the Scopus database, also written by authors from the United States. This indicates that asset management research had already drawn interest from Western scholars in its early development stages. Analysing the documents based on publication years allowed the researchers to observe the evolution of the research topic over time (Ahmi \& Mohamad, 2019).

Slow growth occurred, with an average of six articles per year in the 18 years since asset management was introduced. The trend increased steadily between 1983 and 1999, with an average of 33 documents produced annually. A significant change took place in 2000, with an average of 113 documents being published from 2000 to 2020, perhaps because organisations started to treat asset management as a strategic and integrated process to gain the greatest lifetime effectiveness, utilisation and returns (Pais et al., 2020). Relevant documents appeared most frequently in titles 
INTERNATIONAL JOURNAL OF ACADEMIC RESEARCH IN ACCOUNTING, FINANCE AND MANAGEMENT SCIENCES

Vol. 11, No. 3, 2021, E-ISSN: 2225-8329 @ 2021 HRMARS

related to facilities management, engineering, transportation and maintenance management; they were primarily located in the United States. Additionally, most documents related to asset management research were written in English, because English is a global language and has a major influence on policies and practices (Nunan, 2020).

\section{The Key Areas of Asset Management Research}

The analysis of topic areas, keywords, and titles suggested that asset management research is strongly related to the fields of engineering, business, management and accounting, and computer science, as asset management pertains to various scopes and disciplines within an organisation (Amadi-Echendu et al., 2010).

A crucial element of a paper's content is its keywords, which include various information such as objectives, techniques, and ideologies (Tian et al., 2018). The most frequently used keywords in asset management research clustered into two main subject areas, "asset management" and "maintenance". Analysis of these studies concluded that most asset management studies focus on maintenance, decision-making, information management, facilities management, life-cycle, and office building. This is probably because the Asset Management role is located at the tactical and operational levels that involve the management of data, facilities and projects (Garramone et al., 2020). Therefore, future asset management studies must extend beyond these areas into other disciplines and interdisciplinary approaches. Important research, for instance, on the issue of asset management practice (Ismail et al., 2019) and good governance (Kaganova \& Amoils, 2020) can help improve the importance of asset management become more widely recognised.

\section{Major Players and Collaborations in Asset Management Research}

Analysis conducted on the countries, organisations, researchers and citations indicates that collaboration on asset management research appears to be extensive worldwide. Most research is highly reliant on collaborations among researchers (Su et al., 2015); scientific collaboration involves interactions between researchers, organisations, and countries. The United States was the pioneer in publishing articles on asset management, and this country remains the leading publisher in research on asset management, contributing $19.28 \%$ of the total global publications. This is possibly because the United States was one of the countries that adopted the formal management of physical assets (Naief, 2018), so financial support was received to conduct research there.

Asset management research was also largely collaborative, thus presenting a significant opportunity for asset management studies. Co-authorship can be interpreted as indicating that collaboration was underway, and demonstrated that writers who contributed to the project were working together (Adams, 2013). The results of this study show a wide range of cooperation among academics, institutions and countries in asset management research. According to Zhu et al (2018), most collaborations occur within a single institution, while a small percentage occur between countries.

Global collaboration networks enable developing countries to participate in the knowledge development process, which has historically been dominated by developed nations (PalaciosCallender \& Roberts, 2018). Overall cooperation in asset management research was lacking in both Europe and Asia, possibly because different frameworks were being used for asset management. These applied different approaches based on geographical, economic, structural and cultural factors, 
INTERNATIONAL JOURNAL OF ACADEMIC RESEARCH IN ACCOUNTING, FINANCE AND MANAGEMENT SCIENCES

Vol. 11, No. 3, 2021, E-ISSN: 2225-8329 @ 2021 HRMARS

and the methods of asset management employed. Analysis of the most frequently referenced sources suggested that various countries were cited many times, but the United States, the United Kingdom, Canada and Australia were cited the most. The numerous citations of documents from various countries indicated that authors recognised the scientific communities in other countries, which might lead to the creation of scientific paradigms (Pan et al., 2012).

Collaboration is essential in helping asset management adapt to international frameworks and standards (Naief, 2017, 2018), and allowing the strategic design, management, and implementation of asset management strategies to contribute to overall strategic planning. The ability to exchange knowledge, and combine and strengthen expertise, is augmented by collaboration. It also allows countries to increase the sharing of information from outside an organisation, and they may then benefit from external experience. Additionally, relationships between leading universities and prominent scholars raise a university's academic credibility and broaden a publication's coverage. Knowledge transfer and reinforcement are closely related to the spread of knowledge, which is crucial for effective asset management implementation. However, the degree to which cooperation in asset management research occurs between universities in less-developed countries is uncertain. Working together with other countries, universities, and authors also correlates with the transfer of information and technology, which is essential in the discovery of new knowledge.

\section{Conclusion}

Bibliometric analysis was employed to perform a systematic review of publications concerning asset management research that ranged from 1965 to 2020. Analysis of the evolution of asset management research through the key topics, fields, and collaborations, with information about publication volumes, publication sources, languages, subjects, keywords, titles, countries, main institutions, authors and citations, indicates that asset management research has been extensively developed. According to the results, early research on asset management was conducted by scholars from the West and has consistently expanded and been disseminated around other parts of the world since then. Most asset management research has concentrated on the fields of engineering, business, management and accounting, and computer science, and their related topics. As a consequence, this has limited the generation of different ideas. There has been a growing degree of collaboration on asset management research between researchers or universities from a small number of countries, suggesting that there are fewer viewpoints from different cultural and institutional backgrounds.

The evolution of asset management reflects a rising emphasis on frameworks and asset management practice worldwide. The collaborations and communications on asset management impact knowledge and, practically speaking, implementation, but have focused on particular countries. Cases of such collaboration and communication are particularly limited between Europe and Asia. This study was based only on the Scopus database and the keywords used in document titles. Other databases such as Google Scholar or WOS, or documents that might have discussed asset management but excluded this term from the title, are beyond the scope of this paper. Extending the search range by including abstracts and keywords would probably increase the amount of relevant information and frequencies. Furthermore, it is likely that authors or institutions registered the same name or different spellings were used in the Scopus database, leading to inaccurate author affiliations or productivity information. 
INTERNATIONAL JOURNAL OF ACADEMIC RESEARCH IN ACCOUNTING, FINANCE AND MANAGEMENT SCIENCES

Vol. 11, No. 3, 2021, E-ISSN: 2225-8329 @ 2021 HRMARS

Despite these limitations, this study makes an important contribution to the understanding of asset management research and publication patterns. Each analysis in this study suggests the growth of this field, which could increase the current level of knowledge. This study is an extension of the results contained in the previous literature and employs bibliometric techniques. Several exciting findings demonstrate the rapidly increasing importance of asset management and its dissemination, as well as the need for more research involving collaboration between different countries and domains. Future studies, it is suggested, should explore and bridge any potential gaps that may arise in the context of asset management development, and focus on different practices in asset management across various countries.

\section{References}

Adams, J. (2013). The fourth age of research. Nature, 497(7451), 557-560. https://doi.org/10.1038/497557a

Ahmi, A., \& Mohamad, R. (2019). Bibliometric analysis of global scientific literature on web accessibility. International Journal of Recent Technology and Engineering, 7(6), 250-258.

Ahmi, A., \& Nasir, M. H. (2019). Examining the trend of the research on extensible business reporting language (xbrl): A bibliometric review. International Journal of Innovation, Creativity and Change, 5(2).

Alfatih, S., Leong, M., \& Hee, L. M. (2015). Definition of engineering asset management: A review. Applied Mechanics and Materials, 773-774(2008), 794-798. https://doi.org/10.4028/www.scientific.net/amm.773-774.794

Amadi-Echendu, J. E. (2004). Managing physical assets is a paradigm shift from maintenance. Proceedings of Engineering Management Conference, IEEE International, 3, 1156-1160. https://doi.org/10.1109/iemc.2004.1408874

Amadi-Echendu, J., Willett, R., Brown, K., \& Yang, B. (2010). What is engineering asset management? In Definitions, Concepts and Scope of Engineering Asset Management (pp. 316). Springer London.

Blache, K. M. (2019). Asset Management: Evolution to revolution. Efficient Plant Magazine. https://www.efficientplantmag.com/2019/04/asset-management-evolution-to-revolution/

Bottle, R., Hossein, S., Bottle, A., \& Adesanya, O. (1994). The productivity of British, American and Nigerian chemists compared. Journal of Information Science, 20(3), 211-215. https://doi.org/10.1177/016555159402000307

Campbell, J. D., \& Reyes, J. V. (2014). Uptime: Strategies for Excellence in Maintenance Management. In Vascular (3rd ed., Issue January 2010). CRC Press Taylor \& Francis Group6000 Broken Sound Parkway NW, Suite 300 Boca Raton, FL 33487-2742.

Garramone, M., Moretti, N., Scaioni, M., Ellul, C., Re Cecconi, F., \& Dejaco, M. C. (2020). BIM and GIS INTEGRATION for INFRASTRUCTURE ASSET MANAGEMENT: A BIBLIOMETRIC ANALYSIS. ISPRS Annals of the Photogrammetry, Remote Sensing and Spatial Information Sciences, 6(4/W1), 77-84. https://doi.org/10.5194/isprs-annals-VI-4-W1-2020-77-2020

Gu, Y. (2004). Global knowledge management research: A bibliometric analysis. Scientometrics, 61(2), 171-190. https://doi.org/10.1023/B:SCIE.0000041647.01086.f4

Harvey, G. (1977). Terotechnology the production. The Production Engineer, July/August, 36-39. Hastings, N. A. J. (2015). Physical asset management: With an introduction to ISO55000. In Springer. https://doi.org/10.1007/978-3-319-14777-2 
INTERNATIONAL JOURNAL OF ACADEMIC RESEARCH IN ACCOUNTING, FINANCE AND MANAGEMENT SCIENCES

Vol. 11, No. 3, 2021, E-ISSN: 2225-8329 @ 2021 HRMARS

Ismail, A. H., Saidin, N. F., Saad, S., Mat Dangi, M. R., \& Johari, R. J. (2019). Asset management practices: Malaysian government department perspective. International Journal of Modern Trends in Business Research (IJMTBR), 2(8), 23-40.

Jamali, H. R., \& Nikzad, M. (2011). Article title type and its relation with the number of downloads and citations. Scientometrics, 88(2), 653-661. https://doi.org/10.1007/s11192-011-0412-z

Kaganova, O., \& Amoils, J. M. (2020). Central government property asset management: a review of international changes. Journal of Corporate Real Estate. https://doi.org/10.1108/JCRE-092019-0038

Konstantakos, P. C., Chountalas, P. T., \& Magoutas, A. I. (2019). The contemporary landscape of asset management systems. Quality - Access to Success, 20(169), 10-17.

Laue, M., Brown, K., Scherrer, P., \& Keast, R. (2014). Integrated strategic asset management: Frameworks and dimensions. Third International Engineering Systems Symposium CESUN 2012, Delft University of Technology, 24(December), 75-87. https://doi.org/10.1007/978-3-31902493-6_6

Leiblein, T. W., Tucker, M., Ashall, M., Lee, S. B., Gollnisch, C., \& Hofer, S. (2016). Legionella and risk management in hospitals-A bibliographic research methodology for people responsible for built environment and facility management. International Journal of Hygiene and Environmental Health, 219(8), 890-897. https://doi.org/10.1016/j.ijheh.2016.07.003

Li, Y., Zhang, Y., Wei, J., \& Han, Y. (2019). Status quo and future directions of facility management: A bibliometric-qualitative analysis. International Journal of Strategic Property Management, 23(5), 354-365. https://doi.org/10.3846/ijspm.2019.9943

Mason, A. (2017). Asset Management and Facilities Management-The Same but Different ? Facilities Management. https://workplacefundi.com/2017/04/29/5-ways-asset-management-isdifferent-to-facilities-management

Mastroianni, E., Lancaster, J., Korkmann, B., Opdyke, A., \& Beitelmal, W. (2021). Mitigating infrastructure disaster losses through asset management practices in the Middle East and North Africa region. International Journal of Disaster Risk Reduction, 53(July 2020), 102011. https://doi.org/10.1016/j.ijdrr.2020.102011

Mirhosseini, M., \& Keynia, F. (2021). Asset management and maintenance programming for power distribution systems: A review. IET Generation, Transmission and Distribution, January, 1-11. https://doi.org/10.1049/gtd2.12177

Naief, A. (2017). Physical asset management practices in the Saudi public sector. Built Environment Project and Asset Management, 7(1), 19-31. https://doi.org/10.1108/BEPAM-12-2015-0070

Naief, A. (2018). Article information :A theoretical framework for physical asset management practices. Journal of Quality in Maintenance Engineering, 19(4), 135-150.

Nel, C. B. H., \& Jooste, W. J. L. (2016). A technologically-driven asset management approach to managing physical assets - a literature review and research agenda for 'smart' asset management. South African Journal of Industrial Engineering, 27(4), 50-65. https://doi.org/10.7166/27-4-1478

Nunan, D. (2020). The Impact of English as a Global Language on Educational Policies and Practices in the Asia-Pacific Region. Learner-Centered English Language Education, 37(4), 164-184. https://doi.org/10.4324/9780203096888-14

Pais, E., Farinha, J. T., Cardoso, A. J. M., \& Raposo, H. (2020). Optimizing the life cycle of physical assets - A review. WSEAS Transactions on Systems and Control, 15(October), 417-430. 
INTERNATIONAL JOURNAL OF ACADEMIC RESEARCH IN ACCOUNTING, FINANCE AND

MANAGEMENT SCIENCES

Vol. 11, No. 3, 2021, E-ISSN: 2225-8329 @ 2021 HRMARS

https://doi.org/10.37394/23203.2020.15.42

Palacios-Callender, M., \& Roberts, S. A. (2018). Scientific collaboration of Cuban researchers working in Europe: understanding relations between origin and destination countries. Scientometrics, 117(2), 745-769. https://doi.org/10.1007/s11192-018-2888-2

Pan, R. K., Kaski, K., \& Fortunato, S. (2012). World citation and collaboration networks: Uncovering the role of geography in science. Scientific Reports, 2(November). https://doi.org/10.1038/srep00902

Sara, I. M., Saputra, K. A. K., \& Utama, I. W. K. J. (2021). The Effects of Strategic Planning, Human Resource and Asset Management on Economic Productivity: A Case Study in Indonesia. Journal of Asian Finance, Economics and Business, 8(4), 381-389. https://doi.org/10.13106/jafeb.2021.vol8.no4.0381

Schraven, D., Hartmann, A., \& Dewulf, G. (2011). Effectiveness of infrastructure asset management: Challenges for public agencies. Built Environment Project and Asset Management, 1(1), 61-74. https://doi.org/10.1108/20441241111143786

Schuman, C. A., \& Brent, A. C. (2005). Asset life cycle management: Towards improving physical asset performance in the process industry. International Journal of Operations and Production Management, 25(6), 566-579. https://doi.org/10.1108/01443570510599728

Su, J., Zhai, Q., \& Landström, H. (2015). Entrepreneurship research in China: internationalization or contextualization? Entrepreneurship and Regional Development, 27(January), 50-79. https://doi.org/10.1080/08985626.2014.999718

Sweileh, W. M., Al-Jabi, S. W., AbuTaha, A. S., Zyoud, S. H., Anayah, F. M. A., \& Sawalha, A. F. (2017). Bibliometric analysis of worldwide scientific literature in mobile - health: 2006-2016. BMC Medical Informatics and Decision Making, 17(1), 1-13. https://doi.org/10.1186/s12911-0170476-7

Tian, X., Geng, Y., Sarkis, J., \& Zhong, S. (2018). Trends and features of embodied flows associated with international trade based on bibliometric analysis. Resources, Conservation and Recycling, 131(January), 148-157. https://doi.org/10.1016/j.resconrec.2018.01.002

Wang, Z., Zhao, Y., \& Wang, B. (2018). A bibliometric analysis of climate change adaptation based on massive research literature data. In Journal of Cleaner Production (Vol. 199). Elsevier Ltd. https://doi.org/10.1016/j.jclepro.2018.06.183

Wijnia, Y. (2016). Towards Quantification of Asset Management Optimality. Proceedings of the 10th World Congress on Engineering Asset Management (WCEAM,2015), Wceam 2015, 663-670. https://doi.org/10.1007/978-3-319-27064-7

Zhu, M., Sari, A., \& Bonk, C. J. (2018). A systematic review of MOOC research methods and topics: Comparing 2014-2016 and 2016-2017. EdMedia+ Innovate Learning, 2013, 1673-1682. 